\title{
Fast and efficient insolvency process as one of the preconditions of an outstanding business environment
}

\author{
Valdis Savickis* and Jolanta Dinsberga \\ Rīga Stradiņš University, Riga, Latvia
}

\begin{abstract}
To date, in the articles and publications on the insolvency process, the primary objective of the insolvency process was emphasized - to balance the protection of legal interests of entrepreneurs and their creditors. The author's article, focusing on the basic principles of the insolvency of legal entities, aims at analyzing and examining the link of applicable principles of insolvency processes to preconditions for outstanding business environment. Focus of the topic indirectly addresses the potential of the regions and human capital. Methods applied in the study: 1) general scientific - analytical, descriptive, inductive and deductive; 2) interpretation of legal norms - grammatical, systematic and teleological. Materials, used in the study are political planning documents, documents of international institutions, normative acts, scientific and law literature, and dictionaries. Issues covered in the study: impact of the insolvency proceedings on preconditions for outstanding business environment and the role of the human capital; potential of the regions. Authors, resulting from the study, made the following conclusions: reforms of the insolvency law sphere have formally reached the primary goals, set out in the government level documents, however linkage with higher-level policy planning documents has remained in the second plan during reform process.
\end{abstract}

Key words: business environment, guidelines, insolvency process, modernization, plan, servitude.

\section{Introduction}

Fast and effective - these are the two basic principles that characterize the insolvency process, as defined in Section 6 of the Insolvency Law [1]. In accordance with the principles mentioned above, the insolvency process should be such that, with the least consumption of resources, the goal of the process can be fully achieved, at the same time maintaining the speed of commercial circulation. Whereas, the purpose of the insolvency process, as defined in Section 1 of the Insolvency Law [..] is to promote the honoring of the obligations of a debtor in financial difficulties and, where possible, the renewal of solvency [... [2]. In the course of time the purpose of the insolvency process changed, either from not clearly defined in the first normative act, regulating insolvency proceedings, stating that [..] the principal purpose of bankruptcy proceedings is to satisfy as fully as possible the claims of creditors by obtaining maximum income from the sale of the property of the debtor [..] [3] to clearer and more precise so-called "middle" Insolvency law, stipulating the process is aimed [..] at

* Corresponding author: valdis.savickis@gmail.com

(C) The Authors, published by EDP Sciences. This is an Open Access article distributed under the terms of the Creative Commons Attribution License 4.0 (http://creativecommons.org/licenses/by/4.0/). 
promoting renewal of the solvency of the insolvency subject and protection of the interests of creditors' aggregate in the case of the limited solvency or insolvency of the debtor [..] [4]. Authors made the conclusion that changeable purpose of insolvency process through the normative act changes came to the current regulation, where the interests of creditors prevail over the renewal of the debtor's solvency in order to promote the process of formation of the outstanding business environment. The same thesis was incorporated in the political planning documents on all planning levels and terms. With the approval of the Cabinet of Ministers (hereinafter - Cabinet) on 21st September 2016 of the State Insolvency Policy Development Guidelines 2016-2020 (hereinafter - Guidelines) [5], a link was established with the Latvian National Development Plan for 2014-2020 (hereinafter - Development Plan) [6] and the scope of activities of the Development Plan. One of the main issues of the Development Plan in sphere of entrepreneurship is to promote and ensure an outstanding business environment, as states the Paragraph 135 - Strategic Objective "Outstanding Business Environment". It stated as follows: an outstanding business environment includes a coherent regulatory framework, the operation of a stable state support and monitoring system, public services oriented towards the needs of businesses, clear and competitive environment for the startup and development of business activity so that anyone willing to do so could establish a business, and work and live in Latvia. Creating an outstanding business environment, it cannot be separated from the statement, made in the Development Plan - Vision of Latvia in 2020: "Economic Breakthrough - for the Greater Well-Being of Latvia!" and the territorial potential described in Paragraphs 52 and 53 of the Development Plan are medium-term priorities. On the other hand, Sustainable Development Strategy of Latvia until 2030 (hereinafter - Latvia 2030) [7], defining strategic principles has stated, that "human capital is the most important resource of Latvia [...]" [8]. The insolvency process proceedings, its results and reflection on the business environment in both urban and rural areas are important factors in human capital, that is defined as the basic value and productivity of Latvia's most important resource. This statement is stipulated by Latvia 2030 as an essential factor.

\section{Material and methods}

The article is structured and formatted on the analysis of political planning documents, laws and regulations, documents of international organizations and conclusions drawn by academics/specialists in the field of civil law. The following political planning documents are used in the study: Latvia 2030, Development Plan, Guidelines. The following legislative acts are used in the study: Constitution of the Republic of Latvia, Civil Law, Civil procedure Law, Insolvency Law. The article incorporates the analysis of national level documents as well as analysis of documents of the international institutions such as United Nations, World Bank, European Commission.

Methods used in the article. General scientific methods: descriptive - by identifying the key terms and definitions of the study. Analytical - by studying political planning documents, laws and regulations, opinions of specialists in the field of civil law and civil proceeding law - to identify problems in the context of the matters examined in the study from different perspectives. Dogmatic - by conducting a comprehensive analysis of the legal framework that defines development areas of Latvia, set by the planning documents, insolvency proceedings and their impact on the above mentioned. Induction and deduction - to emphasize the approbations of the will of legislator, expressed in the different level of political planning documents, in laws and regulations, as well as to figure out the compliance and incompliance with the recommendations and course of actions, expressed by the international organizations. The methods of interpretation of legal norms have also 
been applied in the article. Grammatical - by examining the meaning and substance of the notions included in legal norms, assessing legal norms from the grammatical aspect. Systematic - by examining the two basic principles of insolvency proceedings: fast and efficient. Teleological - by examining the intention of the legislator when adopting laws and regulations in relation to above mentioned principles, in correlation with objectives set by the different level of political planning documents.

\section{Discussion}

To date, in the articles and publications on the insolvency process, the primary objective and the sub-objectives of the insolvency process were to balance the protection of legal interests of entrepreneurs and their creditors on the one hand and to maintain a commercially lawful quick turnover on the other hand. The author's article, focusing on the basic principles of the insolvency process of legal entities, aims at analyzing and examining the link of insolvency processes to creating preconditions for outstanding business environment. The focus of the topic addresses the potential of the territories and human capital as well, paying attention to both urban and rural areas.

Authors' analysis, incorporated in the study, bases upon the three objectives or priorities:

1. Outstanding business environment.

2. Potential of the regions.

3. Access to Services.

Outstanding business environment, as the term, was invented by the Development Plan, and it was one of the strategic objectives, defining priority "Growth of the National Economy". Such an objective, as the documentary product of Cross-Sector Coordination Centre, approved by the parliament of the Republic of Latvia, contained four essential elements:

- coherent regulatory framework;

- the operation of a stable state support and monitoring system;

- public services oriented towards the needs of businesses;

- clear and competitive environment for the start-up and development of business activity [9].

And the outcome of the sum of these elements is a predictable result that anyone willing to do the business activity in Latvia, could establish a business, work and live in Latvia.

Potential of the regions, as one of the Sections of a Vision of Latvia in 2020: "Economic Breakthrough - for the Greater Well-Being of Latvia!" was defined as the outcome of the expanded economy and the business activity of people, focusing on the following activities and statements:

- to raise the territorial potential;

- regional development is based on unleashing economic activity;

- to emphasize the sector of small and medium enterprises;

- provision of jobs to regional population [10].

One more essential medium-term priority, subordinating the Vision, mentioned above, is Access to Services. Such priority contains sub-visions, defining predictable outcome:

- rational and well-developed road infrastructure;

- proper roads, connecting the national and regional development centers [11].

Analyzing terms fast and efficient, according to online dictionaries, definitions state that: fast - done in comparatively little time; taking a comparatively short time; to take effect 
quickly; efficient - performing or functioning in the best possible manner with the least waste of time and effort; having and using requisite knowledge, skill, and industry; competent; capable. [12] Authors made an analytical research of the meaning of terms in context of the basic principles of the insolvency process. The current Insolvency Law prescribes both principles, defining that they are the general principles either of legal protection proceedings, or the insolvency proceedings of a legal person and insolvency proceedings of a natural person. Term fast was analyzed in comparison with principle of quick turnover - the task of the proceedings is to maintain a commercially lawful quick turnover; the sale of the property of a debtor shall be performed in order to ensure the return to commercially lawful circulation as quickly as possible [13]. But the term efficient met comparative analysis with the principle of effectiveness of proceedings - such measures which allow the objective of the proceedings to be achieved in a most complete manner with the least resources shall be applicable within the scope of proceedings [14]. Using the comparative method, authors came to conclusion that will of legislator was to set up the basis for the insolvency process, operating with the unified terms and principles of Civil Law and Civil procedure Law. The same opinion on the speed of process shared V. Bukovskis, professor Dr.iur. He indicated, that speed of the process is significant: [..] from the state economic positions it is very important to eliminate uncertainty in disputes as soon as possible [..] and, on other hand [..], the longer the process lasts, the more expensive it costs [..] [15]. Basic economical values and possible risk of rise of expenses characterize the bases of insolvency proceedings and inseparable link with the business environment of the state. The content of the legal norms, defining the meaning of both aforementioned principles also met strong connection with the aim of the insolvency proceedings and purpose of the Insolvency law by itself.

"Effective and efficient" as the key terms, characterizing the insolvency laws, embedded also in the Legislative Guide on Insolvency Law, publication of the United Nations Commission on International Trade Law (hereinafter - Legislative Guide) [16]. The base and principles for the actual Insolvency law of the Republic of Latvia also was the aforementioned Legislative Guide. As stated in the Legislative Guide, basic principles of provisions for timely, efficient and impartial resolution of insolvency are critical to incorporate them in the normative act. It means that insolvency should be addressed and resolved in an orderly, quick and efficient manner, avoiding undue disruption of the debtor's business activities and minimizing the cost of the proceedings [17].

Considering that insolvency, according to Doing Business index and Global Competitiveness, is one of the factors/indicators, measuring the business environment in a particular country, authors can make conclusion that both terms "fast and efficient", and principles of quick turnover and effectiveness of proceedings clearly link the essential elements of Outstanding business environment, mentioned above.

To get clearer vision of the applicable principles, authors make the analysis of the reforms of insolvency sphere in Latvia. Taking into account that one of the main reasons for the reforms was the global financial crisis (2008) and Latvia's loan from the World Bank in the amount of 200 million euro, the rehabilitation of the financial sector served as one of the incentives for reform and modernization in the area of regulation of the insolvency process. However, the aforementioned financial injections into the economy of Latvia implied a list of "homework assignments" compiled in the Implementation completion and results report on a loan in the amount of 200 million euro to Republic of Latvia financial sector development policy plan [18], with a rather tight control of a team of experts appointed by the World Bank and the International Monetary Fund. One of the objectives, set by this international financial institution was distressed asset management, prescribing the Reform of the corporate and personal insolvency regimes - new Insolvency Law, and it was reached by the Republic of Latvia in June 26th, 2010 [19]. 
Another institution that influenced the modernisation process of insolvency sphere and especially the speed of the insolvency process - was European Union Council. In its recommendation of July 9, 2013, Point (16) of the Preamble stated, that [..] "Disposition times are particularly long for insolvency proceedings". Moreover, many cases do not get settled at first instance, which creates delays at all levels, up to the Supreme Court [..] [20]. Aforementioned statement indicated significant value of the principle of quick turnover, as well as the necessary speed of the process - fast insolvency proceedings. Accordingly, recommended actions there indicated for Latvia to [..] reduce the backlog and length of insolvency [..] [21].

Formation and legislative process of adoption of the current Insolvency law was emphasized in the annotation of the draft of the law (hereinafter - Annotation) [22]. According to Annotation, draft of the law included international preconditions and tasks of actions as well as national level regulations, invented by the Government of the Republic of Latvia:

- Republic of Latvia: letter of Intent and Technical Memorandum of Understanding, July 27, 2009 (The following document is the Letter of Intent of the government of Republic of Latvia, which describes the policies that Republic of Latvia intends to implement in the context of its request for financial support from the International Monetary Fund) [23];

- International Bank for Reconstruction and Development program document for a proposed loan in the amount of 200 million euro to Republic of Latvia for a financial sector development policy, August 25, 2009 (The document subordinates a long-term structural reform, including strengthening critical regulations both in the sphere of state and private sector of Republic of Latvia) [24];

- Cabinet order "On the Action Plan for the Implementation of the Latvian Economic Stabilization and Growth Recovery Program", February 19, 2009 [25];

- Cabinet order "On the Business Environment Improvement Plan 2009”, January 16, 2009 [26].

The key task of the draft of the current Insolvency law, included in the Section 4 of Annotation, stated that [..] he Entrepreneurship Improvement Action Plan sets out a number of tasks aimed at improving the regulation of insolvency proceedings [..] [27]. This statement clearly corresponds with the statement made by the authors in the title of the article and resulting from the study - fast and efficient insolvency proceedings and clear and sufficient normative regulation is one of the preconditions for the outstanding business environment.

Coming back to key objectives and priorities - Potential of the regions and Access to Services, authors emphasize that it is possible to talk about accessibility both nationally and internationally. However, before discussion on the international level, discussion of accessibility issues at the national level is necessary. In the opinion of the authors, first of all the existing roads and new roads should be improved in Latvia, as well as the existing problems related to access to property by servitude roads set during the land reform. During the land reform the State Land Service, and the Land Commissions and municipalities had legal basis for determining the servitude of the road by an administrative act. Their decision based, for example, upon the Law "On Land Privatisation in Rural Areas" [28], Law "About land use and land survey" [29], Law "On State and Municipal Property Ownership and their Corroboration in Land Registers" [30]. Unfortunately, with regard to the determination of road servitudes, these authorities had made a number of legal shortcomings in their decisions, which in many cases today do not fulfill their primary function of providing access to real estate and access to services that are not on the public road. To solve the existing problems, 
the Cabinet on October 29, 2013 issued the decision - Protocol No.56, §105 [31]. It required from the Ministry of Environmental Protection and Regional Development in cooperation with the Ministry of Transport, the Ministry of Justice and the Ministry of Agriculture to prepare and submit to the Cabinet for consideration an informative report on problems arising from road servitudes, established during the land reform, as well as possible solutions for their arrangement. The task was carried out basing on the study "On servitudes of right of way established by administrative acts during land reform" [32]. It resulted in the Conceptual Report "On Problems with Road Servitudes and Their Possible Solutions Established during Land Reform" [33]. However, the task given to the above-mentioned ministries and the developed Conceptual Report lost their relevance along with the report submitted by the Minister for Environmental Protection and Regional Development "Informative Report on the Protocol Decision of the Cabinet of Ministers of October 29, 2013 (Prot. No. 56, §105)". The Bill on Land Management Law" for the Ministry of Environmental Protection and Regional Development, the Ministry of Transport, the Ministry of Justice and the Ministry of Agriculture has lost recognition of the task as topical [34]. According to the informative report - problems related to servitude can be solved in accordance with the norms of the Civil Law. Therefore, it is not appropriate to introduce an administrative process. If the road is necessary for public use, the municipality may commence the alienation of the property for the needs of the public; in case the state or local government road to the land of a private person already exists in nature, the public interest is ensured in accordance with Article 8 of the Land Management Law.

Evaluating the existing legal mechanisms for implementing accessibility in accordance with the "Latvia 2030", the authors see several shortcomings that negatively affect and / or completely paralyze business development. 1) On the basis of authors' practical experience, it should be noted that in case the road servitude is established by court, the process of litigation may last for 3-5 years on average, and in a situation when insolvency proceedings take place, even longer. 2) When assessing Section 8 of the Land Management Law, it should be noted that the process of alienation of immovable property for the needs of the public is long lasting. The reason is that a number of consecutive actions have to be performed in order to prepare a draft law on alienation of the respective immovable property and accepted in the Parliament of Latvia. One of the features of business environment is speed and dynamics, therefore it is unacceptable that accessibility issues are solved slowly and not in democratic manner.

Authors' special attention is addressed to the Section $8 .^{1}$ of the Land Management Law, redaction of the Law after amendments of 27 September 2018, that entry in force on 25 October 2018. Within the framework of the before said Section, a new concept of a term "A road or street of local importance" was introduced [35]. According to the second Part of the Section $8 .{ }^{1}$ of the Land Management Law, the municipality shall determine the road or street of the municipality as the road/street of local significance. Assigning of the status of a street of local significance has to be done by a separate administrative act accompanied by a graphic annex [36]. Authors concluded that a road which is a private property, and not registered as a municipal or state road, but is incorporated in a municipal or state balance is declared as the road or street of local significance. It is done even without providing for a fair reward as defined in Article 105 of the Constitution of the Republic of Latvia [37]. In the opinion of the authors, the legislator has broadened the interpretation of Article 105 of the Constitution of the Republic of Latvia with regard to the restriction of property rights by law and has adopted a legal norm in compliance with the principles of justice, legitimate expectations and good governance is discussible. This legal norm also comes in conflict with Article 927 of the Civil Law [38] that the property is the power of power over the matter. Consequently, this legal situation clearly does not correspond to the statements, made by the "Latvia 2030", in which human capital - inhabitants of Latvia is main priority. 
Coming to the human capital, the most important resource of Latvia, authors emphasize that neither in political planning documents, nor in legal norms there is no strict regulation on protection of people (inhabitants of Latvia), indirectly suffering from the results of insolvency proceedings of legal entities, especially in the rural areas of Latvia. Effect of the insolvency proceedings also covers such spheres as workplaces; unpaid taxes (especially in social sphere); infrastructure.

\section{Results and conclusion}

As a result of the research, the authors have concluded, that the basic principles of the insolvency process, such as principle of quick turnover and effectiveness of proceedings, correspond to fast and effective insolvency process, formatted during reforms of the insolvency law sphere performed by the legislator. These reforms have formally reached the primary goals and sub-goals, set out in the Guidelines:

- Basic principles of insolvency proceedings: effectiveness of proceedings and principle of quick turnover, formatted in strict collaboration of the internationally provided guidelines and proposals, underlining the close interaction with the economic processes, minimizing costs of all parties, involved in the process.

- Correlation of those principles is significant, viewing both from linguistic perspective and from invention of objectives and primary goals, set by legislator in different level political planning documents.

- Above mentioned principles create link to the preconditions of the outstanding business environment, particularly such elements as coherent regulatory framework, stable state support and monitoring system, clear and competitive environment for the start-up and development of business activity.

- Outstanding business environment, as the primary objective, analyzed by authors in this article and set by the Development Plan corresponds to the Vision of Latvia in 2020: "Economic Breakthrough - for the Greater Well-Being of Latvia!" and some priorities and preconditions, set by the higher-level planning documents.

- Private and especially servitude roads, as unfinished process, during the period of the land reform did not fulfil their purpose and primary aim of the Development Plan - to promote the Potentials of regions and create Access to services.

- Legal norms, introduced by the legislator in the sphere of potential of regions and access to services, do not clearly correspond to the Constitution of the Republic of Latvia and priorities, set by the Latvia 2030.

On the other hand, linkage with higher-level policy planning documents, in particular the priorities defined in the Latvia 2030, has remained in the second plan, thus degrading the priorities set by the legislator, such as territorial potential and human capital.

\section{References}

[1] Insolvency Law (2010), Latvijas Vēstnesis 124(4316), Section 6

[2] Insolvency Law (2010), Latvijas Vēstnesis 124(4316), Section 1

[3] Law "On the Insolvency of Undertakings and Companies" (1996) not in force, Latvijas Vēstnesis 165(650), Section 102 (1996), Ziņotājs 20 (1996)

[4] Insolvency Law (2008) not in force, Latvijas Vēstnesis 188(3764), (2007), Ziņotājs, 24, (2007)

[5] 21.09.2016 Cabinet Order No.527, Latvijas Vēstnesis 186(5758), (2016) 
[6] National Development Plan of Latvia for 2014-2020. Approved by a Decision of the Saeima on 20 December 2012. Available at: http://www.pkc.gov.lv/ sites/default/files/images-legacy/NAP2020\%20dokumenti/NDP2020_

English_Final.pdf

[7] Sustainable Development Strategy of Latvia until 2030. Approved by a Statement of Saeima on 10 February 2010. Available at: http://www.pkc. gov.lv/sites/default/files/images-legacy/LV2030/LIAS_2030_en.pdf

[8] Sustainable Development Strategy of Latvia until 2030. Approved by a Statement of Saeima on 10 February 2010, Paragraph 17

[9] National Development Plan of Latvia for 2014-2020. Approved by a Decision of the Saeima on 20 December 2012, Paragraph 135

[10] National Development Plan of Latvia for 2014-2020. Approved by a Decision of the Saeima on 20 December 2012, Paragraph 52-53

[11] National Development Plan of Latvia for 2014-2020. Approved by a Decision of the Saeima on 20 December 2012, Paragraph 54-55

[12] Dictionary.com, online source for English definitions, synonyms, word origins. Available at: https://www.dictionary.com

[13] Insolvency Law (2010), Latvijas Vēstnesis 124(4316), Section 6, Point 6 (2010)

[14] Insolvency Law (2010), Latvijas Vēstnesis 124(4316), Section 6, Point 5 (2010)

[15] V. Bukovskis, Civil procedure textbook, 252 (1933)

[16] UN publication.Legislative Guide on Insolvency Law (2005). Available at: https://www.uncitral.org/pdf/english/texts/insolven/05-80722_

Ebook.pdf

[17] UN publication. Legislative Guide on Insolvency Law, 12 (2005)

[18] Document of World Bank. Report No: ICR00001791 (2010) Available at: http://documents. worldbank.org/curated/en/611351468300294254/pdf/ ICR17910P115701e0only1910B0X358322B.pdf

[19] Document of World Bank. Report No: ICR00001791, 23 (2010)

[20] European Union document. Council Recommendation of 9 July 2013 on the National Reform Program 2013 of Latvia and delivering a Council opinion on the Convergence Program of Latvia, 2012-2016, 3 (2013) Available at: https : //eur-lex. europa.eu/legal-content/EN/TXT/?uri=CELEX\% 3А32013H0730\%2812\%29

[21] European Union document. Council Recommendation of 9 July 2013 on the National Reform Programme 2013 of Latvia and delivering a Council opinion on the Convergence Programme of Latvia, 2012-2016, 4 (2013)

[22] Annotation to the draft of the Insolvency law, December 03, 2009. No.90/TA-3941. Available at: https://titania.saeima.1v/LIVS/SaeimaLIVS.nsf/webAll? SearchView\&Query=\%28 [NumberTxt] =1621/Lp9\%29\&SearchMax=0\& SearchOrder $=4$

[23] Republic of Latvia: Letter of Intent and Technical Memorandum of Understanding, http://www.fm.gov.lv/prevfiles/preses_relizes/dok/Letter_of_Intent_ 2009-07-27.pdf

[24] Document of World Bank. Report No.49937-LV. Available at: http:// documents . worldbank.org/curated/en/402111468278331650/text/ 499370PGD0P1151e0only10R20091022411.txt

[25] 19.02.2009. Cabinet order No.123, Latvijas Vēstnesis 30(5758), (2016)

[26] 16.01.2009. Cabinet order No.35, Latvijas Vēstnesis 13(3999), (2009) 
[27] Annotation to the draft of the Insolvency law, December 03, 2009. No.90/TA-3941, 90 (2009)

[28] Law "On Land Privatisation in Rural Areas", Section 22 (1992). Latvijas Republikas Augstākās Padomes un Valdības Ziņotājs 32/33/34 (1992)

[29] Law "About land use and land survey", Section 20 Part 3 (1991) not in force // Latvijas Republikas Augstākās Padomes un Valdības Ziņotājs 31/32 (1991). Diena 146 (1991)

[30] Law "On State and Municipal Property Ownership and their Corroboration in Land Registers”, Section 9, Part 5, Point 1 (1995), Latvijas Vēstnesis 56(339) (1995), Latvijas Republikas Saeimas un Ministru Kabineta Ziņotājs 10 (1995)

[31] 29.10.2013 Protocol decision of the Cabinet of Ministers No.56, §105 "Problems with road servitudes established during the land reform and their possible solutions" (2013), Latvijas Vēstnesis 216 (2013)

[32] M. Auders, Study "On servitudes of right of way established by administrative acts during land reform" (2014) Available at: http://petijumi.mk.gov. lv/sites/default/files/title_file/petijums_varam_2014_par\%20zemes\% 20reformas $\% 20$ laika $\% 20$ ar $\% 20$ administrativo $\% 20$ aktu $\% 20$ nodibinatiem $\%$ 20 celu\%20servitutiem. DOCX

[33] Conceptual Report "On Problems with Road Servitudes and Their Possible Solutions Established during Land Reform" (2016) unpublished. Available at Ministry of Environmental Protection and Regional Development

[34] Report "Informative Report on the Protocol Decision of the Cabinet of Ministers of October 29, 2013 (prot. No. 56, §105)" The Bill on Land Management Law" for the Ministry of Environmental Protection and Regional Development, the Ministry of Transport, the Ministry of Justice and the Ministry of Agriculture has lost recognition of the task as topical" (2017) Available at: http:// tap.mk.gov.1v/doc/2017_11/VARAMzino_250117_Servituti.658.docx

[35] Land Management Law, Section 8..$^{1}$ (2015), Latvijas Vēstnesis 228(5288), (2014)

[36] Land Management Law, Section 8. ${ }^{1}$, Part 2 (2015), Latvijas Vēstnesis 228(5288), (2014)

[37] Constitution of the Republic of Latvia, Article 105 (1992), Latvijas Vēstnesis 43 (1993), Latvijas Republikas Saeimas un Ministru Kabineta Ziņotājs 6 (1994), Valdības Vēstnesis 141 (1922), Diena 81 (1993)

[38] Civil Law, Article 927 (1937/1992), Valdības Vēstnesis 41 (1937) 